IZA DP No. 10071

Booster Seats and Traffic Fatalities among Children

D. Mark Anderson

Sina Sandholt

July 2016 


\title{
Booster Seats and Traffic Fatalities among Children
}

\author{
D. Mark Anderson \\ Montana State University \\ and IZA
}

\section{Sina Sandholt}

Columbia University

\section{Discussion Paper No. 10071 \\ July 2016}

\author{
IZA \\ P.O. Box 7240 \\ 53072 Bonn \\ Germany \\ Phone: +49-228-3894-0 \\ Fax: +49-228-3894-180 \\ E-mail: iza@iza.org
}

\begin{abstract}
Any opinions expressed here are those of the author(s) and not those of IZA. Research published in this series may include views on policy, but the institute itself takes no institutional policy positions. The IZA research network is committed to the IZA Guiding Principles of Research Integrity.

The Institute for the Study of Labor (IZA) in Bonn is a local and virtual international research center and a place of communication between science, politics and business. IZA is an independent nonprofit organization supported by Deutsche Post Foundation. The center is associated with the University of Bonn and offers a stimulating research environment through its international network, workshops and conferences, data service, project support, research visits and doctoral program. IZA engages in (i) original and internationally competitive research in all fields of labor economics, (ii) development of policy concepts, and (iii) dissemination of research results and concepts to the interested public.
\end{abstract}

IZA Discussion Papers often represent preliminary work and are circulated to encourage discussion. Citation of such a paper should account for its provisional character. A revised version may be available directly from the author. 


\section{ABSTRACT}

\section{Booster Seats and Traffic Fatalities among Children*}

In an effort to increase booster seat use among children, the National Highway Traffic Safety Administration is encouraging state legislators to promote stricter booster seat laws, yet there is a paucity of information on booster seat efficacy relative to other forms of restraint. Using data from the Fatality Analysis Reporting System for the period 2008-2014 and the sample selection correction proposed by Levitt and Porter (2001), the current study examines the effectiveness of booster seats relative to child safety seats and adult seat belts. For children 6 to 8 years of age, we find that booster seats are more than twice as effective as child safety seats and over 30 percent more effective than standard seat belts at decreasing the likelihood of fatality in a motor vehicle accident. For children 2 to 5 years of age, all three forms of restraint appear equally effective.

\section{JEL Classification: $\quad$ I12, I18}

Keywords: booster seats, child safety seats, traffic fatalities

Corresponding author:

D. Mark Anderson

Department of Agricultural Economics and Economics

Montana State University

P.O. Box 172920

Bozeman, MT 59717-2920

USA

E-mail: dwight.anderson@montana.edu

\footnotetext{
* We thank Dean Anderson, Chad Cotti, Chris Stoddard, Carly Urban, and participants at the 2015 Southern Economic Association Annual Meeting for comments and suggestions. Partial support for this research came from a Eunice Kennedy Shriver National Institute of Child Health and Human Development research infrastructure grant, R24 HD042828, to the Center for Studies in Demography and Ecology at the University of Washington.
} 


\section{INTRODUCTION}

Motor vehicle accidents are the leading cause of injury deaths among children ages one and older in the United States (Decina et al. 2008; Centers for Disease Control and Prevention 2015). To curb these high fatality rates, decades of legislation have taken aim at protecting child passengers. For instance, early laws during the 1970s and 1980s mandated the use of child safety seats (Bae et al. 2014). More recently, states have revised their child restraint laws to include booster seat requirements (Decina et al. 2008). ${ }^{1}$ Booster seats are intended for children who have outgrown their child safety seat but are too small to use a standard adult seat belt. Our goal is to provide the first credible estimates on the effectiveness of booster seats at saving children's lives in motor vehicle accidents.

Not surprisingly, there is a large literature on the relationship between the use of various restraint devices and traffic fatalities among children (see, e.g., Kahane 1986; Partyka 1988; Hertz 1996; Elliot et al. 2006; Rice and Anderson 2009; Rice et al. 2009). But, what is surprising is that most studies evaluate the effectiveness of these devices relative to riding unrestrained, as opposed to riding in a standard seat belt. Moreover, they do not take into account the sample selection problem associated with analyzing data on fatal motor vehicle crashes. Specifically, if restraint use influences the likelihood of dying, then a data set on fatal motor vehicle crashes is not representative of all crashes in the United States.

\footnotetext{
${ }^{1}$ Booster seat laws vary along several margins. For example, the ages covered by these laws range from 5 to 8 and some states specify weight and/or height thresholds for which a booster seat is required. The enforcement of booster seat laws also differs widely. Similar to seat belt laws, some booster seat laws are primary; police may stop vehicles solely for violating the law. In other states, booster seat laws are secondary; police must have an additional reason to make a stop. Fines range from $\$ 5$ to $\$ 500$ and some states count points against a driver's license or insurance for noncompliance (Decina et al. 2008). Florida is the most recent state to pass a booster seat law. As of January 1, 2015, children in Florida are required to ride in a crash-tested, federally approved car or booster seat until the age of 6 (Jacobson 2015). To date, South Dakota is the only state without booster seat legislation (Governors Highway Safety Association 2016).
} 
The exception to the literature is Levitt (2008). Using data from the National Highway Traffic Safety Administration's (NHTSA) Fatality Analysis Reporting System (FARS) for the period 1975-2003 and the sample selection correction proposed by Levitt and Porter (2001), Levitt (2008) found that child restraint devices do not provide a noticeable safety improvement over adult seat belts. However, due to data limitations, Levitt (2008) was unable to distinguish between different types of child restraint devices.

We exploit a recent innovation in the FARS that was unavailable to Levitt (2008) and other previous researchers and examine the effectiveness of booster seats relative to child car seats and adult seat belts. Prior to 2008 , children riding in booster seats or child safety seats were simply recorded within the same restraint device category. Using data for the period 20082014 and also applying Levitt and Porter's (2001) sample selection correction, we find that booster seats are the superior form of restraint for children 6 to 8 years of age. Specifically, booster seats are more than twice as effective than child safety seats and over 30 percent more effective than standard seat belts at decreasing the likelihood of fatality. The safety-enhancing effects of booster seats do not, however, extend to younger children ages 2 through 5 . For these children, we cannot reject the hypotheses that booster seats are equally effective as child safety seats or standard seat belts. These results support recommendations made by the NHTSA and the American Academy of Pediatrics (AAP) that booster seat efficacy depends to a large extent on the size of the child (Durbin 2011; NHTSA 2015).

Our findings have clear policy relevance as funding decisions for the NHTSA's vehicle and behavioral safety programs rely on information from their crash data sets, such as the FARS 
(NHTSA 2013). ${ }^{2}$ In addition, the NHTSA has outlined educational and enforcement strategies to improve the effectiveness of booster seat legislation. For instance, educational strategies include public messaging campaigns aimed at increasing parental knowledge of booster seat safety.

Enforcement strategies include increased law enforcement training and judicial outreach (Decina et al. 2008). ${ }^{3}$ It is important that policy decisions such as these be based on reliable estimates of booster seat effectiveness. To our knowledge, our paper is the first to provide such estimates.

\section{BACKGROUND}

Booster seats have become increasingly popular for children who have outgrown their child safety seat but are too small to use a standard adult seat belt. In 1995, only 6 percent of children weighing 40 to 60 pounds used a child safety seat or a booster seat (Decina and Knoebel 1997). In 2013, 44 percent of children weighing 40 to 60 pounds and 46 percent of children 4 to 7 years of age rode in a booster seat (Pickrell and Choi 2014). According to Arbogast et al. (2009), booster seats have become the most common form of restraint among 4 to 5 year olds. The AAP has even included questions on booster seats in their physician guidelines for wellchild visits (Hagan et al. 2008).

Booster seats are made to improve seat belt fit by raising the position of the child and, for most models, by altering the route of the seat belt. Anatomically proper fit is characterized by belt placement where the force of the belt is directed onto the skeleton as opposed to soft tissues (Reed et al. 2013). If seat belts are not positioned correctly, they can slice into internal organs

\footnotetext{
2 The NHTSA's fiscal year 2016 budget request totaled $\$ 908$ million and included $\$ 179$ million for vehicle safety, $\$ 152$ million for behavioral safety, and \$577 million for state grants and high visibility enforcement support (NHTSA 2016).

${ }^{3}$ The NHTSA recommends that law enforcement officers complete a child passenger safety certification course, with a component in the curriculum on booster seats. The NHTSA also promotes educating local magistrates and other judiciary members to enhance their understanding of booster seat laws (Decina et al. 2008).
} 
(O'Donnell 2011). During a crash, the lap portion of the belt should engage with the front of the pelvis and the shoulder portion of the belt should engage with the clavicle (Reed et al. 2013). ${ }^{4}$

Because belt positioning is critical for the safety of the child, premature graduation from a child safety seat to a booster seat or from a booster seat to a seat belt could be particularly dangerous. Likewise, research has suggested that it is unsafe to keep a child in a particular restraint device after they have outgrown it (Pickrell and Choi 2013). Even if a child is of the appropriate age and size for a booster seat, parental error during the installation process can also complicate matters. According to the Insurance Institute for Highway Safety, many parents do not understand that the purpose of a booster seat is to ensure proper seat belt fit (O'Donnell 2011). A recent field study by the NHTSA found that roughly 10 percent of children in booster seats had the lap belt sitting too high, across the child's stomach (Newman 2015). It appears installation issues are even more common with child safety seats. The same study found that nearly 50 percent of child safety seats were installed or used incorrectly (Newman 2015).

\section{PREVIOUS STUDIES}

Since Peltzman's (1975) seminal work, economists have been interested in traffic safety restraint devices and the legislation governing their use. ${ }^{5}$ The majority of this research has

\footnotetext{
${ }^{4}$ Pediatricians recommend that parents use the following five-step test to determine if their child is too small for an adult seat belt:

1.) Does the child sit all the way back against the auto seat?

2.) Do the child's knees bend comfortably at the edge of the auto seat?

3.) Does the belt cross the shoulder between the neck and the arm?

4.) Is the lap belt as low as possible, touching the thighs?

5.) Can the child stay seated like this for the whole trip?

If parents answer "no" to any of these questions, then a booster seat is recommended (Pediatric Center 2005).

${ }^{5}$ Peltzman (1975) introduced the concept that benefits from vehicle safety regulation may be offset by a compensating increase in risk taking by drivers.
} 
focused on seat belts. For instance, Levitt and Porter (2001), Cohen and Einav (2003), and Sen and Mizzen (2007) studied the relationship between seat belt usage and the risk of traffic fatality. ${ }^{6}$ Relatedly, Sen (2001), Morrisey and Grabowski (2005), and Carpenter and Stehr (2008) estimated the reduced-form relationship between mandatory seat belt laws and traffic fatality rates in the United States. ${ }^{7}$ In general, these studies provide overwhelming support for the case that seat belts and the laws mandating their use promote driver safety. Other traffic safety-device-related research has studied the effects of air bags (Peterson et al. 1995; Levitt and Porter 2001), motorcycle helmets (Sass and Leigh 1991; Sass and Zimmerman 2000; Dee 2009; Dickert-Conlin et al. 2011), and vehicle safety inspections (Merrell et al. 1999). ${ }^{8}$

The literature on child restraint devices is quite large. However, earlier studies only evaluated their effectiveness relative to riding unrestrained and did not make comparisons to seat belts (see, e.g., Kahane 1986; Partyka 1988; Hertz 1996). ${ }^{9}$ While more recent studies make this comparison, they do not address sample selection bias due to the manner in which data sets on traffic fatalities are constructed (see, e.g., Elliot et al. 2006; Rice and Anderson 2009; Rice et al. 2009). Specifically, restraint use likely influences whether or not an accident is included in the

\footnotetext{
${ }^{6}$ Levitt and Porter (2001) found that wearing a seat belt reduces the likelihood of death by approximately 60 percent. Cohen and Einav (2003) estimated the relationship between seat belt usage and traffic fatality rates at the state level, using mandatory seat belt laws as instrumental variables. Sen and Mizzen (2007) used province-level data from Canada and a similar empirical strategy. Both studies found evidence of a negative relationship between seat belt usage and traffic fatality rates.

${ }^{7}$ Sen (2001) found that mandatory seat belt legislation was associated with a 21 percent decline in driver fatalities. Morrisey and Grabowski (2005) focused on older drivers and found that primary seatbelt laws reduced fatalities by roughly 13 percent for 65 to 74 year olds. Carpenter and Stehr (2008) found that primary seatbelt laws reduced traffic fatalities among individuals 14 to 18 years of age by approximately 8 percent.

${ }^{8}$ Economists have studied a wide array of policies that influence traffic fatality rates. For example, research has focused on alcohol and drug policies (Dee 2001; Carpenter and Dobkin 2009; Grant 2010; Anderson et al. 2013; Anderson and Rees 2015), automobile insurance and accident liability laws (Cohen and Dehejia 2004), graduated driver licensing laws (Dee et al. 2005), minimum wage laws (Adams et al. 2012), smoking bans (Adams and Cotti 2008), and texting bans (Abouk and Adams 2013).

${ }^{9}$ As pointed out by Levitt (2008), these studies do report results for both child safety seats and seat belts. However, they do not test the hypothesis that the estimates for these two types of restraint are equal.
} 
data. Using the sample selection correction from Levitt and Porter (2001), which we describe in more detail below, Levitt (2008) is the exception to this literature. ${ }^{10}$ As noted above, Levitt (2008) found that child restraint devices do not provide a noticeable improvement over standard seat belts in reducing motor vehicle fatalities among children.

We build upon Levitt (2008) in two important ways. First, given a recent innovation in the FARS data that was unavailable to Levitt (2008), we are able to discern between child safety seats and booster seats. Prior to 2008 , both types of restraint were simply lumped into the same category within the FARS data. Being able to distinguish between restraint types is vital as booster seats are rapidly gaining in popularity among parents, yet there are no credible estimates on their effectiveness at decreasing fatality risk. Second, by studying the period 2008-2014, our focus is on more recent data. This is important for booster seats and child safety seats alike as substantial technological improvements have been and continue to be made over time (Zaloshnja and Miller 2007; Robinson 2014; Automotive Safety Program 2015).

\section{DATA AND EMPIRICAL STRATEGY}

As stated above, we use annual data from the Fatality Analysis Reporting System (FARS) for the period 2008-2014 to examine the relationship between booster seat use and the likelihood

\footnotetext{
${ }^{10}$ While the focus of our paper is on fatal traffic accidents, it is also important to note the work by Doyle and Levitt (2010). These authors used data from the General Estimates Survey, the New Jersey Department of Transportation, and the Wisconsin Crash Outcome Data Evaluation System to estimate the relationship between child restraint device use and traffic injuries. For the two most serious injury categories ("fatal/incapacitating" and "nonincapacitating" injuries), they found no difference between child restraint devices and standard seat belts. For the least serious injury category ("possible" injuries), they found that child restraint devices outperformed seat belts. Similar to Levitt (2008), they were unable to distinguish between different types of child restraint devices.
} 
of fatality. These data are compiled by the NHTSA and represent a census of all fatal injuries resulting from motor vehicle accidents in the United States. ${ }^{11}$

We restrict the data set along several margins. First, we limit the sample to children 2 to 8 years of age. The vast majority of children under the age of 2 in the data are in child safety seats or ride unrestrained. Children over the age of 8 are almost exclusively in standard adult seat belts or ride unrestrained. ${ }^{12}$ Second, we limit the sample to occupants of passenger cars and light trucks. ${ }^{13}$ This effectively excludes accidents in which the only fatalities are to pedestrians, motorcyclists, or passengers of large trucks (e.g., moving trucks or semis), buses, or other nonstandard vehicles (e.g., limousines, motor homes, ATVs). Lastly, we drop individuals from the sample with unknown or missing information on age, restraint type, or injury severity.

Table 1 provides descriptive statistics on fatal injuries by restraint type. For children 2 to 8 years of age, approximately 31 percent die who ride unrestrained. This estimate is slightly higher for the younger children in the sample (2 to 5 year olds). For children in booster seats, their fatality rates are higher than those for children in child safety seats or standard seat belts. Child safety seats and seat belts appear similar in terms of raw fatality rates.

However, it is unlikely that raw fatality rates reflect causal estimates. Factors such as vehicle type, crash severity, and the driver's own risk preference are likely simultaneously correlated with the choice of child restraint and the risk of being involved in a fatal accident.

\footnotetext{
${ }^{11}$ Information on the details of each accident comes from a variety of sources: police reports, driver licensing files, vehicle registration files, state highway department data, emergency medical services records, medical examiner reports, toxicology reports, and death certificates. Additional information on how the FARS data are collected is available at: http://www.nhtsa.gov/FARS.

${ }^{12}$ It is worth noting that Levitt (2008) focused his sample on children 2 to 6 years of age. Given the more recent time period we study, it is important for us to include 6 to 8 year olds in our sample. Because booster seats were a rare phenomenon during Levitt's (2008) time period of interest, very few 6 to 8 year olds would have been recorded in the FARS data as having ridden in a child restraint device.

${ }^{13}$ Based on the definition of "light trucks" from the FARS, this category includes vehicles such as SUVs, utility station wagons, vans, compact pickup trucks, and standard pickup trucks. Roughly 90 percent of children 2 to 8 years of age in the data were occupants of a passenger car or a light truck.
} 
Additionally, child restraint device use may influence whether or not a crash is included in the data set. In this regard, there is sample selection bias that is unaccounted for when focusing on simple means (Levitt and Porter 2001; Levitt 2008).

In an effort to control for factors simultaneously correlated with child restraint choice and traffic fatality risk, we estimate the following equation:

$$
\begin{aligned}
& \text { Fatality }_{i v c t}=\beta_{0}+\beta_{1} \text { Booster Seat }_{i v c t}+\beta_{2} \text { Child Seat }_{i v c t}+\beta_{3} \text { Seat Belt Only }{ }_{i v c t} \\
& +\boldsymbol{X}_{i v c t} \boldsymbol{\beta}_{5}+\boldsymbol{X}_{\boldsymbol{v}_{v c t} \boldsymbol{\beta}_{6}}+\boldsymbol{X} \mathbf{3}_{c t} \boldsymbol{\beta}_{7}+\varepsilon_{i v c t},
\end{aligned}
$$

where Fatality ivct $_{\text {is }}$ equal to one if child $i$ in vehicle $v$, crash $c$, and year $t$ died, and is equal to zero otherwise. The variables Booster Seat $t_{i v c t}$, Child Seat ${ }_{i v c t}$, and Seat Belt Only $y_{i v c t}$ are mutually exclusive indicators for the type of restraint device used. ${ }^{14}$ The omitted category is no restraint use. The vector $\boldsymbol{X} \boldsymbol{I}_{\text {ivct }}$ includes individual-level controls for seat position (front, back left, back middle, back right, back 'other'), gender, and age. It is important to control for seat position because children in booster seats and child safety seats are more likely to ride in the back than children in adult seat belts or children riding unrestrained. ${ }^{15}$ Research suggests that sitting in a back seat may reduce the risk of death, especially for children (Smith and Cummings 2006).

\footnotetext{
${ }^{14}$ The primary departure of our estimating equation from that of Levitt's (2008) is that our variable Seat Belt Only covers both lap-and-shoulder and lap-only seat belts. Levitt (2008) included separate indicators for each type of seat belt. For his sample, a nearly equal proportion of children were restrained in lap-and-shoulder and lap-only belts. In our sample, children in lap-and-shoulder belts outnumber those in lap-only belts approximately 6 to 1 . This reflects the fact that lap-only belts are being phased out of existence. Since 1989, the NHTSA has required that all rear outboard seats in new passenger vehicles be equipped with lap-and-shoulder belts. In 2004, the NHTSA ruled that all rear center seats in new passenger vehicles must be equipped with lap-and-shoulder belts by 2008 (NHTSA 2005). Our results change little if we drop children restrained in lap-only belts from the sample.

${ }^{15}$ Roughly 95 percent of children in booster seats or child safety seats were in a back seat. On the other hand, approximately 85 percent of children in adult seat belts or riding unrestrained were in a back seat.
} 
The vector $\boldsymbol{X} \mathbf{2}_{v c t}$ includes vehicle-level controls for vehicle type, model year, vehicle weight, point of impact, seat belt status of the driver, the driver's injury severity, and the driver's accident and violation history. Seat belt status of the driver and the driver's accident and violation history serve as proxies for unobserved driver tastes and preferences. For instance, safer drivers may be more likely to appropriately restrain their child passengers. In interviews with nearly 1,500 parents of children 4 to 9 years of age, Bruce et al. (2011) found that the strongest determinants of the intent to use a booster seat were parental attitudes and beliefs. The severity of the driver's injury proxies for the severity of the accident.

The vector $\boldsymbol{X} \boldsymbol{3}_{c t}$ includes crash-level controls for the number of persons and cars involved, the speed limit, road type, time of day, whether the crash occurred on a weekend, and year of the crash. The number of persons involved in the accident also serves as a proxy for crash severity. Because the FARS data only include fatal accidents, the more people who are involved in the accident, the more likely the accident is included in the data set (Levitt 2008). Following Levitt (2008), all regressions are estimated as linear probability models and standard errors are corrected for clustering at the vehicle level. This level of clustering takes into account the fact that there are sometimes multiple child passengers in the same vehicle. ${ }^{16}$

Table 2 illustrates definitions and descriptive statistics for the control variables used in the analysis. Means are provided for the full sample and for samples restricted by restraint type. Over 70 percent of the sample rode restrained by some type of device. This is significantly higher than the approximate 44 percent who rode restrained in Levitt's (2008) sample, reflecting

\footnotetext{
${ }^{16}$ Following Doyle and Levitt (2010), we also control for interactions between driver seat belt status and driver injuries. To restrain sample size, we include dummy variables to indicate missing information on seat position, gender, point of contact, driver characteristics, vehicle characteristics, and crash characteristics. Finally, we experimented with clustering the standard errors at the accident level. Inference based on this level of clustering was similar to that based on clustering at the vehicle level.
} 
an increasing trend in restraint device use. Unrestrained children were more likely to have ridden in an older vehicle and with a driver who was also unbelted, suffered a serious injury, and had been charged with a driving violation in the past 3 years. Unrestrained children were also much more likely to have been in a one-car or early morning accident.

Because the FARS data include only crashes where at least one person died and restraint devices likely affect the probability of death, there is a sample selection problem. Failing to account for this problem will result in estimates that understate the true value of effective restraint devices. To address the sample selection issue, we follow Levitt and Porter (2001) and limit the sample to two-car crashes where someone in the other vehicle died. ${ }^{17}$ Holding other factors constant, the assumption is that restraint choice in one vehicle is independent of the fatality outcomes in the other vehicle. This sample selection correction breaks the link between one's restraint choice and their inclusion in the data set (Levitt 2008). ${ }^{18}$

\section{RESULTS}

Table 3 presents the main results of the paper. Panel I provides estimates from specifications without the sample selection correction. For each age group, estimates are shown from models with and without the covariates listed in Table 2. Across all ages and all types of restraint devices, estimates are negative and statistically significant at the one percent level. For children 2 to 8 years of age and controlling for the covariates listed in Table 2, booster seats

\footnotetext{
${ }^{17}$ See Levitt and Porter (2001) for a formal treatment of the sample selection problem.

${ }^{18}$ Levitt (2008) importantly points out that the subset of crashes based on the sample selection correction are generally less severe than the average crash in the data set. As a result, it is not necessarily clear that estimates based on the corrected sample generalize to all crashes. Levitt (2008) also emphasizes that the Peltzman (1975) effect, where restraint use promotes aggressive driving, could lead to biased estimates when restraint use by the driver in the other vehicle is not taken into account. For our models based on the sample selection correction, we control for the seat belt status of the other driver. We also control for characteristics of the other vehicle (weight and type) and the other driver's accident history and prior driving violation charges.
} 
reduce the probability of fatality by 10.3 percentage points. This equates to roughly a 33 percent reduction relative to the mean fatality rate for unrestrained children. While this represents a sizable reduction, child safety seats and standard seat belts appear more effective. In fact, we reject the null hypotheses that the coefficient estimate on Booster Seat is equal to the coefficient estimate on Child Seat or the coefficient estimate on Seat Belt Only. Child safety seats and standard seat belts appear similarly effective. Inference changes little when limiting the sample to 2 to 5 year olds or 6 to 8 year olds.

Panel II illustrates results from our preferred specifications based on the sample selection correction. In general, the sizes of the coefficient estimates are smaller than those in Panel I. This reflects the fact that these crashes are typically less severe than those based on the entire sample. For children 2 to 8 years of age and controlling for the covariates listed in Table 2, riding in a booster seat is associated with a decrease in the probability of fatality by 6 percentage points. This represents slightly more than a 50 percent decrease relative to the mean fatality rate for unrestrained children. As expected, the magnitude of the effect is larger in the sample corrected for selection. In this case, we fail to reject the null hypotheses that the coefficient estimate on Booster Seat is equal to the coefficient estimate on Child Seat or the coefficient estimate on Seat Belt Only. All three types of restraint appear similarly effective.

When splitting the sample by age, we see a different pattern of results. For children 2 to 5 years of age, the magnitude of the coefficient estimate on Child Seat is roughly double the effect associated with Booster Seat. This is consistent with the notion that premature graduation from a child safety seat to a booster seat can be particularly dangerous (Pickrell and Choi 2014). However, it is important to note that the booster seat estimate is measured imprecisely and we cannot reject the hypothesis that child seats and booster seats are equally effective at 
conventional levels of statistical significance $(\mathrm{p}$-value $=.115)$. The results for this younger age group also suggest that standard seat belts are nearly twice as safe as booster seats. But, again, we cannot reject the hypothesis that these effect sizes are equal. Lastly, and consistent with Levitt's (2008) findings, child safety seats seemingly afford the same level of protection against fatal injuries as do standard seat belts.

For older children, the estimates suggest that booster seats are the superior form of restraint. Controlling for the covariates listed in Table 2, the size of the booster seat effect is over twice as large as that for child safety seats and over 30 percent larger than that for standard seat belts. At the 5 percent level of significance, we reject the hypotheses that the coefficient estimate on Booster Seat is equal to the coefficient estimate on Child Seat or the coefficient estimate on Seat Belt Only. We fail to reject equality between the coefficient estimates on Child Seat and Seat Belt Only, but this is due to the imprecision with which the estimate on Child Seat is measured. ${ }^{19}$

\section{CONCLUSION}

In the past 20 years, booster seats have gone from almost nonexistent to one of the more popular choices of child car restraint (Decina and Knoebel 1997; Pickrell and Choi 2014). Despite this trend and an intense public interest in child traffic safety, credible estimates on the effectiveness of booster seats at saving children's lives are absent from the literature.

To examine the relationship between booster seat use and the risk of fatality, we draw upon data from the Fatality Analysis Reporting System (FARS) for the period 2008-2014. Until a recent innovation in the FARS data, researchers had been unable to examine booster seat

\footnotetext{
${ }^{19}$ Because the cell size is small for children 6 to 8 years of age in child safety seats, this estimate should be interpreted with caution.
} 
effectiveness. In 2008, the FARS began distinguishing between booster seats and child safety seats in its crash reports. Using a sample selection correction proposed by Levitt and Porter (2001) and employed by Levitt (2008), we find that booster seat effectiveness varies by age. For the older children in our sample (6 to 8 year olds), our results suggest that booster seats are the superior form of restraint. In particular, booster seats are more than twice as effective than child safety seats and over 30 percent more effective than standard seat belts at reducing the risk of fatality. For the younger children in our sample (2 to 5 year olds), we cannot reject the hypotheses that booster seats are equally effective as child safety seats or standard seat belts. From a policy perspective, these results are vital as federal, state, and local governments must decide on how to best allocate their budgets earmarked for traffic safety. Our findings also provide important information for state legislatures contemplating particular age cutoffs for their booster seat requirements.

A caveat to our results is that they reflect how booster seats are used in practice. While Newman (2015) estimated improper installation to be substantially lower for booster seats relative to child safety seats, the misuse of booster seats would cause our estimates to understate their true value. Another caveat to our results is that we only consider fatal injuries. While the FARS data are ideal for studying traffic fatalities, they are not the appropriate data source for studying non-fatal injuries. Exploring the relationship between booster seats and non-fatal injuries is an important line of inquiry for future research. 


\section{REFERENCES}

Abouk, Rahi and Scott Adams. 2013. "Texting Bans and Fatal Accidents on Roadways: Do They Work? Or Do Drivers Just React to Announcements of Bans?" American Economic Journal: Applied Economics 5: 179-199.

Adams, Scott, McKinley Blackburn, and Chad Cotti. 2012. "Minimum Wages and AlcoholRelated Traffic Fatalities among Teens." Review of Economics and Statistics 94: 828840.

Adams, Scott and Chad Cotti. 2008. "Drunk Driving After the Passage of Smoking Bans in Bars." Journal of Public Economics 92: 1288-1305.

Anderson, D. Mark, Benjamin Hansen, and Daniel Rees. 2013. "Medical Marijuana Laws, Traffic Fatalities, and Alcohol Consumption." Journal of Law and Economics 56: 333369.

Anderson, D. Mark and Daniel Rees. 2015. "Per Se Drugged Driving Laws and Traffic Fatalities." International Review of Law and Economics 42: 122-134.

Arbogast, Kristy, Jessica Jermakian, Michael Kallan, and Dennis Durbin. 2009. "Effectiveness of Belt Positioning Booster Seats: An Updated Assessment." Pediatrics 124: 1281-1286.

Automotive Safety Program. 2015. "'Life' of a Child Safety Seat." Available at: http://www.preventinjury.org/Child-Passenger-Safety/About-Child-Safety-Seats/Life-ofA-Child-Safety-Seat.

Bae, Jin Yung, Evan Anderson, Diana Silver, and James Macinko. 2014. "Child Passenger Safety Laws in the United States, 1978-2010: Policy Diffusion in the Absence of Strong Federal Intervention." Social Science and Medicine 100: 30-37.

Bruce, Beth, Anne Snowdon, Charles Cunningham, Carolyn Cramm, Krista Whittle, Heather Correale, Melanie Barwick, Caroline Piotrowski, Lynne Warda, and Jessie Harold. 2011. "Predicting Parents' Use of Booster Seats." Injury Prevention 17: 313-318.

Carpenter, Christopher and Carlos Dobkin. 2009. "The Effect of Alcohol Consumption on Mortality: Regression Discontinuity Evidence from the Minimum Drinking Age." American Economic Journal: Applied Economics 1: 164-182.

Carpenter, Christopher and Mark Stehr. 2008. "The Effects of Mandatory Seatbelt Laws on Seatbelt Use, Motor Vehicle Fatalities, and Crash-Related Injuries among Youths." Journal of Health Economics 27: 642-662.

Centers for Disease Control and Prevention. 2015. "Ten Leading Causes of Death and Injury." Available at: http://www.cdc.gov/injury/wisqars/leadingcauses.html. 
Cohen, Alma and Rajeev Dehejia. 2004. "The Effect of Automobile Insurance and Accident Liability Laws on Traffic Fatalities." Journal of Law and Economics 47: 357-393.

Cohen, Alma and Liran Einav. 2003. "The Effects of Mandatory Seat Belt Laws on Driving Behavior and Traffic Fatalities." Review of Economics and Statistics 85: 828-843.

Decina, Lawrence and Kathleen Knoebel. 1997. "Child Safety Seat Misuse Patterns in Four States.” Accident Analysis and Prevention 29: 125-132.

Decina, Lawrence, Kathy Lococo, Warren Ashburn, William Hall, and Janelle Rose. 2008. "Identifying Strategies to Improve the Effectiveness of Booster Seat Laws." NHTSA Report No DOT HS 810969.

Dee, Thomas. 2001. "Does Setting Limits Save Lives? The Case of 0.08 BAC Laws." Journal of Policy Analysis and Management 20: 113-130.

Dee, Thomas. 2009. "Motorcycle Helmets and Traffic Safety." Journal of Health Economics 28: 398-412.

Dee, Thomas, David Grabowski, and Michael Morrisey. 2005. "Graduated Driver Licensing and Teen Traffic Fatalities." Journal of Health Economics 24: 571-589.

Dickert-Conlin, Stacy, Todd Elder, and Brian Moore. 2011. "Donorcycles: Motorcycle Helmet Laws and the Supply of Organ Donors." Journal of Law and Economics 54: 907-935.

Doyle, Joseph and Steven Levitt. 2010. "Evaluating the Effectiveness of Child Safety Seats and Seat Belts in Protecting Children from Injury." Economic Inquiry 48: 521-536.

Durbin, Dennis. 2011. “Technical Report - Child Passenger Safety.” Pediatrics 127: e1050e1066.

Elliott, Michael, Michael Kallan, Dennis Durbin, and Flaura Winston. 2006. "Effectiveness of Child Safety Seats vs Seat Belts in Reducing Risk for Death in Children in Passenger Vehicle Crashes." Archives of Pediatrics and Adolescent Medicine 160: 617-621.

Governors Highway Safety Association. 2016. "Child Passenger Safety Laws.” Available at: http://www.ghsa.org/html/stateinfo/laws/childsafety_laws.html.

Grant, Darren. 2010. "Dead on Arrival: Zero Tolerance Laws Don't Work." Economic Inquiry 48: 756-770.

Hagan, Joseph, Judith Shaw, and Paula Duncan. 2008. Bright Futures: Guidelines for Health Supervision of Infants, Children, and Adolescents, Third Edition. Elk Grove Village, IL: American Academy of Pediatrics.

Hertz, E. 1996. "Revised Estimates of Child Restraint Effectiveness.” NHTSA Research Note. 
Jacobson, Susan. 2015. "Florida Strengthens Child Booster-Seat Law.” Orlando Sentinel. Available at: http://www.orlandosentinel.com/news/os-booster-seats-new-florida-law-20150126story.html.

Kahane, Charles. 1986. "An Evaluation of Child Passenger Safety: The Effectiveness and Benefits of Safety Seats.” NHTSA Report No DOT HS 806890.

Levitt, Steven. 2008. "Evidence that Seat Belts are as Effective as Child Safety Seats in Preventing Death for Children Aged Two and Up." Review of Economics and Statistics 90: 158-163.

Levitt, Steven and Jack Porter. 2001. "Sample Selection in the Estimation of Air Bag and Seat Belt Effectiveness." Review of Economics and Statistics 83: 603-615.

Merrell, David, Marc Poitras, and Daniel Sutter. 1999. "The Effectiveness of Vehicle Safety Inspections: An Analysis Using Panel Data." Southern Economic Journal 65: 571-583.

Morrisey, Michael and David Grabowski. 2005. "State Motor Vehicle Laws and Older Drivers." Health Economics 14: 407-419.

NHTSA. 2005. "Improving the Safety of Older-Child Passengers." Available at: http://icsw.nhtsa.gov/people/injury/childps/boosterseatprogress/.

NHTSA. 2013. "Fiscal Year 2013 Budget Overview." Available at: http://www.nhtsa.gov/Laws+\&+Regulations/NHTSA+Budget+Information.

NHTSA. 2015. "Know the Facts About Booster Seats." Available at: http://www.nhtsa.gov/people/injury/childps/archive/promote/know.htm.

NHTSA. 2016. "Fiscal Year 2016 Budget Overview." Available at: http://www.nhtsa.gov/Laws+\&+Regulations/NHTSA+Budget+Information.

Newman, Jennifer. 2015. "Nearly Half of Kid's Car Seats Installed Incorrectly." USA Today. Available at: http://www.usatoday.com/story/money/cars/2015/07/09/kid-car-seatsinstalled/29916055/.

O'Donnell, Jayne. 2011. "Car-Safety Group: Half of Child Booster Seats Pose Risks." USA Today. Available at: http://usatoday30.usatoday.com/money/autos/story/2011-10-13/boosterseats/50747988/1.

Partyka, Susan. 1988. "Lives Saved by Child Restraints from 1982 through 1987." NHTSA Report No DOT HS 807371. 
Pediatric Center. 2005. "Boosters Are For Big Kids." Available at: http://www.thepediatriccenter.net/docs/beuf/SharedAssets/Booster.pdf.

Peltzman, Sam. 1975. "The Effects of Automobile Safety Regulation." Journal of Political Economy 83: 677-726.

Peterson, Steven, George Hoffer, and Edward Millner. 1995. "Are Drivers of Air-Bag-Equipped Cars More Aggressive? A Test of the Offsetting Behavior Hypothesis." Journal of Law and Economics 38: 251-263.

Pickrell, Timothy and Eun-Ha Choi. 2014. "The 2013 National Survey of the Use of Booster Seats.” NHTSA Report No DOT HS 812037.

Reed, Matthew, Sheila Ebert-Hamilton, Kathleen Klinich, Miriam Manary, and Jonathan Rupp. 2013. "Effects of Vehicle Seat and Belt Geometry on Belt Fit for Children with and without Belt Positioning Booster Seats." Accident Analysis and Prevention 50: 512-522.

Rice, Thomas and Craig Anderson. 2009. "The Effectiveness of Child Restraint Systems for Children Aged 3 Years or Younger during Motor Vehicle Collisions: 1996 to 2005." American Journal of Public Health 99: 252-257.

Rice, Thomas, Craig Anderson, and A. Lee. 2009. "The Association between Booster Seat Use and Risk of Death among Motor Vehicle Occupants Aged 4-8: A Matched Cohort Study." Injury Prevention 15: 379-383.

Robinson, Kim. 2014. "Booster Seats: The Science Junkie's Guide.” Car Seats for the Littles. Available at: http://csftl.org/booster-science/.

Sass, Tim and J. Paul Leigh. 1991. "The Market for Safety Regulation and the Effect of Regulation on Fatalities: The Case of Motorcycle Helmet Laws." Review of Economics and Statistics 73: 167-172.

Sass, Tim and Paul Zimmerman. 2000. "Motorcycle Helmet Laws and Motorcyclist Fatalities." Journal of Regulatory Economics 18: 195-215.

Sen, Anindya. 2001. "An Empirical Test of the Offset Hypothesis." Journal of Law and Economics 44: 481-510.

Sen, Anindya and Brent Mizzen. 2007. "Estimating the Impact of Seat Belt Use on Traffic Fatalities: Empirical Evidence from Canada." Canadian Public Policy 33: 315-335.

Smith, Kathleen and Peter Cummings. 2006. "Passenger Seating Position and the Risk of Passenger Death in Traffic Crashes: A Matched Cohort Study." Injury Prevention 12: 8386. 
Zaloshnja, Eduard and Ted Miller. 2007. "The Economic Benefits of Child Safety Seat Misuse Reduction Programs and Design Improvements for Children in Rear Seats." Annual Proceedings for the Association for the Advancement of Automotive Medicine 51: 197206. 
Table 1. Descriptive Statistics on Fatal Injuries by Restraint Type

\begin{tabular}{|c|c|c|c|c|c|}
\hline & Full sample & $\begin{array}{c}\text { No Restraint } \\
=1\end{array}$ & $\begin{array}{c}\text { Booster Seat } \\
=1\end{array}$ & $\begin{array}{l}\text { Child Seat } \\
\quad=1\end{array}$ & $\begin{array}{c}\text { Seat Belt Only } \\
=1\end{array}$ \\
\hline \multicolumn{6}{|l|}{ Ages 2-8 } \\
\hline \multirow[t]{2}{*}{ Fatality } & .172 & .311 & .203 & .111 & .106 \\
\hline & $(.377)$ & $(.463)$ & $(.403)$ & $(.314)$ & $(.308)$ \\
\hline $\mathrm{N}$ & 10,845 & 2,946 & 1,057 & 1,780 & 5,062 \\
\hline \multicolumn{6}{|l|}{ Ages $2-5$} \\
\hline \multirow[t]{2}{*}{ Fatality } & .190 & .324 & .222 & .112 & .124 \\
\hline & $(.392)$ & $(.468)$ & $(.416)$ & $(.315)$ & $(.330)$ \\
\hline $\mathrm{N}$ & 5,467 & 1,583 & 630 & 1,635 & 1,619 \\
\hline \multicolumn{6}{|l|}{ Ages 6-8 } \\
\hline \multirow[t]{2}{*}{ Fatality } & .154 & .296 & .176 & .097 & .098 \\
\hline & $(.361)$ & $(.457)$ & $(.381)$ & $(.296)$ & $(.297)$ \\
\hline $\mathrm{N}$ & 5,378 & 1,363 & 427 & 145 & 3,443 \\
\hline
\end{tabular}

Notes: Fatality is equal to one if the child died, and is equal to zero otherwise. Each cell represents the percentage of children who were fatally injured by restraint type. Means (with standard deviations in parentheses) are based on unweighted data from the Fatality Analysis Reporting System (2008-2014). 


\section{Table 2. Descriptive Statistics on Independent Variables by Restraint Type}

\begin{tabular}{|c|c|c|c|c|c|c|}
\hline & $\begin{array}{c}\text { Full } \\
\text { sample }\end{array}$ & $\begin{array}{c}\text { No } \\
\text { Restraint } \\
=1\end{array}$ & $\begin{array}{l}\text { Booster } \\
\text { Seat }=1\end{array}$ & $\begin{array}{c}\text { Child } \\
\text { Seat }=1\end{array}$ & $\begin{array}{l}\text { Seat Belt } \\
\text { Only }=1\end{array}$ & Description \\
\hline \multicolumn{7}{|c|}{ Individual-level characteristics } \\
\hline \multicolumn{7}{|l|}{ Restraint type } \\
\hline No Restraint & $\begin{array}{l}.272 \\
(.445)\end{array}$ & 1.00 & $\ldots$ & $\ldots$ & $\ldots$ & $=1$ if child was unrestrained, $=0$ otherwise \\
\hline Booster Seat & $\begin{array}{l}.097 \\
(.297)\end{array}$ & $\ldots$ & 1.00 & $\ldots$ & $\ldots$ & $=1$ if child was in a booster seat, $=0$ otherwise \\
\hline Child Seat & $\begin{array}{l}.164 \\
(.370)\end{array}$ & $\ldots$ & $\ldots$ & 1.00 & $\ldots$ & $=1$ if child was in a child seat, $=0$ otherwise \\
\hline Seat Belt Only & $\begin{array}{l}.467 \\
(.499)\end{array}$ & $\ldots$ & $\ldots$ & $\ldots$ & 1.00 & $=1$ if child was in a seat belt only,$=0$ otherwise \\
\hline \multicolumn{7}{|l|}{ Child seat position } \\
\hline Front & $\begin{array}{l}.120 \\
(.325)\end{array}$ & $\begin{array}{l}.139 \\
(.346)\end{array}$ & $\begin{array}{l}.055 \\
(.228)\end{array}$ & $\begin{array}{l}.038 \\
(.190)\end{array}$ & $\begin{array}{l}.152 \\
(.359)\end{array}$ & $\begin{array}{l}=1 \text { if child was sitting in the front of the vehicle, } \\
=0 \text { otherwise }\end{array}$ \\
\hline Back Left & $\begin{array}{l}.310 \\
(.463)\end{array}$ & $\begin{array}{l}.227 \\
(.419)\end{array}$ & $\begin{array}{c}.389 \\
(.488)\end{array}$ & $\begin{array}{l}.367 \\
(.482)\end{array}$ & $\begin{array}{l}.323 \\
(.468)\end{array}$ & $\begin{array}{l}=1 \text { if child was sitting in the back left of the } \\
\text { vehicle, }=0 \text { otherwise }\end{array}$ \\
\hline Back Middle & $\begin{array}{l}.175 \\
(.380)\end{array}$ & $\begin{array}{c}.221 \\
(.415)\end{array}$ & $\begin{array}{l}.113 \\
(.316)\end{array}$ & $\begin{array}{c}.174 \\
(.379)\end{array}$ & $\begin{array}{c}.162 \\
(.368)\end{array}$ & $\begin{array}{l}=1 \text { if child was sitting in the back middle of the } \\
\text { vehicle }=0 \text { otherwise }\end{array}$ \\
\hline Back Right & $\begin{array}{l}.317 \\
(.465)\end{array}$ & $\begin{array}{c}.205 \\
(.404)\end{array}$ & $\begin{array}{c}.432 \\
(.496)\end{array}$ & $\begin{array}{c}.406 \\
(.491)\end{array}$ & $\begin{array}{l}.327 \\
(.469)\end{array}$ & $\begin{array}{l}=1 \text { if child was sitting in the back right of the } \\
\text { vehicle, }=0 \text { otherwise }\end{array}$ \\
\hline Back Other & $\begin{array}{l}.045 \\
(.208)\end{array}$ & $\begin{array}{l}.124 \\
(.330)\end{array}$ & $\begin{array}{l}.006 \\
(.075)\end{array}$ & $\begin{array}{l}.009 \\
(.094)\end{array}$ & $\begin{array}{l}.021 \\
(.143)\end{array}$ & $\begin{array}{l}=1 \text { if child was sitting in an "other" position in } \\
\text { the back of the vehicle, }=0 \text { otherwise }\end{array}$ \\
\hline Male & $\begin{array}{l}.515 \\
(.500)\end{array}$ & $\begin{array}{l}.516 \\
(.500)\end{array}$ & $\begin{array}{l}.518 \\
(.500)\end{array}$ & $\begin{array}{l}.515 \\
(.500)\end{array}$ & $\begin{array}{l}.513 \\
(.500)\end{array}$ & $=1$ if male,$=0$ otherwise \\
\hline Age 2 & $\begin{array}{l}.107 \\
(.309)\end{array}$ & $\begin{array}{c}.109 \\
(.311)\end{array}$ & $\begin{array}{c}.062 \\
(.242)\end{array}$ & $\begin{array}{l}.333 \\
(.471)\end{array}$ & $\begin{array}{l}.036 \\
(.186)\end{array}$ & $=1$ if two years of age, $=0$ otherwise \\
\hline Age 3 & $\begin{array}{l}.119 \\
(.324)\end{array}$ & $\begin{array}{c}.133 \\
(.340)\end{array}$ & $\begin{array}{l}.120 \\
(.325)\end{array}$ & $\begin{array}{l}.275 \\
(.447)\end{array}$ & $\begin{array}{l}.056 \\
(.231)\end{array}$ & $=1$ if three years of age, $=0$ otherwise \\
\hline Age 4 & $\begin{array}{l}.135 \\
(.342)\end{array}$ & $\begin{array}{l}.148 \\
(.355)\end{array}$ & $\begin{array}{l}.197 \\
(.398)\end{array}$ & $\begin{array}{l}.198 \\
(.399)\end{array}$ & $\begin{array}{l}.092 \\
(.290)\end{array}$ & $=1$ if four years of age, $=0$ otherwise \\
\hline Age 5 & $\begin{array}{c}.143 \\
(.350)\end{array}$ & $\begin{array}{l}.148 \\
(.355)\end{array}$ & $\begin{array}{l}.217 \\
(.412)\end{array}$ & $\begin{array}{l}.112 \\
(.316)\end{array}$ & $\begin{array}{l}.135 \\
(.342)\end{array}$ & $=1$ if five years of age, $=0$ otherwise \\
\hline Age 6 & $\begin{array}{c}.152 \\
(.359)\end{array}$ & $\begin{array}{c}.142 \\
(.349)\end{array}$ & $\begin{array}{l}.200 \\
(.400)\end{array}$ & $\begin{array}{l}.055 \\
(.228)\end{array}$ & $\begin{array}{l}.183 \\
(.386)\end{array}$ & $=1$ if six years of age, $=0$ otherwise \\
\hline Age 7 & $\begin{array}{c}.164 \\
(.370)\end{array}$ & $\begin{array}{c}.163 \\
(.369)\end{array}$ & $\begin{array}{l}.141 \\
(.348)\end{array}$ & $\begin{array}{l}.023 \\
(.150)\end{array}$ & $\begin{array}{l}.219 \\
(.414)\end{array}$ & $=1$ if seven years of age, $=0$ otherwise \\
\hline Age 8 & $\begin{array}{l}.180 \\
(.384)\end{array}$ & $\begin{array}{l}.159 \\
(.365)\end{array}$ & $\begin{array}{l}.063 \\
(.244)\end{array}$ & $\begin{array}{l}.003 \\
(.058)\end{array}$ & $\begin{array}{l}.278 \\
(.448)\end{array}$ & $=1$ if eight years of age, $=0$ otherwise \\
\hline \multicolumn{7}{|l|}{ Vehicle-level characteristics } \\
\hline Car & $\begin{array}{l}.380 \\
(.485)\end{array}$ & $\begin{array}{c}.352 \\
(.478)\end{array}$ & $\begin{array}{l}.407 \\
(.491)\end{array}$ & $\begin{array}{l}.393 \\
(.488)\end{array}$ & $\begin{array}{l}.387 \\
(.487)\end{array}$ & $=1$ if vehicle was a car, $=0$ otherwise \\
\hline Model Year $\leq 1990$ & $\begin{array}{c}.029 \\
(.167)\end{array}$ & $\begin{array}{c}.051 \\
(.221)\end{array}$ & $\begin{array}{c}.015 \\
(.122)\end{array}$ & $\begin{array}{c}.019 \\
(.135)\end{array}$ & $\begin{array}{c}.022 \\
(.146)\end{array}$ & $\begin{array}{l}=1 \text { if vehicle model year was pre } 1991,=0 \\
\text { otherwise }\end{array}$ \\
\hline $1990<$ Model Year $\leq 2000$ & $\begin{array}{l}. .148 \\
.348 \\
(.476)\end{array}$ & $\begin{array}{c}.434 \\
(.496)\end{array}$ & $\begin{array}{c}.302 \\
(.459)\end{array}$ & $\begin{array}{l}.270 \\
(.444)\end{array}$ & $\begin{array}{l}.335 \\
(.472)\end{array}$ & $\begin{array}{l}=1 \text { if vehicle model year was between } 1991 \text { and } \\
2000,=0 \text { otherwise }\end{array}$ \\
\hline Model Year > 2000 & $\begin{array}{l}.622 \\
(.485)\end{array}$ & $\begin{array}{l}.513 \\
(.500)\end{array}$ & $\begin{array}{c}.681 \\
(.466)\end{array}$ & $\begin{array}{c}.710 \\
(.454)\end{array}$ & $\begin{array}{c}.643 \\
(.479)\end{array}$ & $\begin{array}{l}=1 \text { if vehicle model year was post } 2000,=0 \\
\text { otherwise }\end{array}$ \\
\hline Vehicle Weight $(1,000$ s lbs. $)$ & $\begin{array}{c}1.88 \\
(1.98)\end{array}$ & $\begin{array}{c}1.95 \\
(1.98)\end{array}$ & $\begin{array}{c}1.48 \\
(1.91)\end{array}$ & $\begin{array}{c}1.72 \\
(1.97)\end{array}$ & $\begin{array}{c}1.97 \\
(1.99)\end{array}$ & Vehicle weight in thousands of pounds \\
\hline \multicolumn{7}{|l|}{ Point of impact } \\
\hline Non-Collision & $\begin{array}{l}.109 \\
(.311)\end{array}$ & $\begin{array}{l}.230 \\
(.421)\end{array}$ & $\begin{array}{l}.062 \\
(.242)\end{array}$ & $\begin{array}{l}.056 \\
(.230)\end{array}$ & $\begin{array}{l}.066 \\
(.248)\end{array}$ & $\begin{array}{l}=1 \text { if initial point of contact was classified as } \\
\text { "non-collision", }=0 \text { otherwise }\end{array}$ \\
\hline Direct Front & .468 & .352 & .505 & .502 & .515 & $=1$ if initial point of contact was at the direct front \\
\hline
\end{tabular}




\begin{tabular}{|c|c|c|c|c|c|c|}
\hline \multirow{3}{*}{ Partial Front } & (.499) & $(.478)$ & $(.500)$ & $(.500)$ & $(.500)$ & of the vehicle, $=0$ otherwise \\
\hline & .125 & .114 & .131 & .139 & .124 & $=1$ if initial point of contact was at the partial \\
\hline & $(.330)$ & $(.318)$ & $(.337)$ & $(.346)$ & $(.330)$ & front of the vehicle, $=0$ otherwise \\
\hline \multirow[t]{2}{*}{ Direct Rear } & .079 & .051 & .082 & .096 & .088 & $=1$ if initial point of contact was at the direct rear \\
\hline & $(.269)$ & $(.219)$ & $(.275)$ & $(.295)$ & $(.283)$ & of the vehicle,$=0$ otherwise \\
\hline \multirow[t]{2}{*}{ Partial Rear } & .051 & .054 & .056 & .047 & .049 & $=1$ if initial point of contact was at the partial rear \\
\hline & $(.219)$ & $(.226)$ & $(.230)$ & $(.211)$ & $(.216)$ & of the vehicle, $=0$ otherwise \\
\hline \multirow[t]{2}{*}{ Right Side } & .063 & .073 & .063 & .054 & .061 & $=1$ if initial point of contact was at the right side \\
\hline & $(.243)$ & $(.260)$ & $(.244)$ & $(.226)$ & $(.239)$ & of the vehicle, $=0$ otherwise \\
\hline Left Side & $\begin{array}{c}.066 \\
(.249)\end{array}$ & $\begin{array}{c}.070 \\
(.254)\end{array}$ & $\begin{array}{c}.067 \\
(.250)\end{array}$ & $\begin{array}{c}.078 \\
(.268)\end{array}$ & $\begin{array}{c}.060 \\
(.238)\end{array}$ & $\begin{array}{l}=1 \text { if initial point of contact was at the left side of } \\
\text { the vehicle, }=0 \text { otherwise }\end{array}$ \\
\hline \multirow[t]{2}{*}{ Other Contact Point } & .023 & .026 & .021 & .021 & .023 & $=1$ if initial point of contact was at an "other" \\
\hline & $(.151)$ & $(.160)$ & $(.143)$ & $(.143)$ & $(.151)$ & contact point, $=0$ otherwise \\
\hline \multirow[t]{2}{*}{ Driver Unbelted } & .209 & .455 & .133 & .115 & .115 & $=1$ if driver was unbelted, $=0$ otherwise \\
\hline & $(.407)$ & $(.498)$ & $(.340)$ & (.319) & (.319) & \\
\hline \multirow[t]{2}{*}{ Driver Uninjured } & .251 & .109 & .218 & .310 & .320 & $=1$ if driver was uninjured, $=0$ otherwise \\
\hline & $(.434)$ & $(.311)$ & (.413) & $(.462)$ & (.467) & \\
\hline \multirow[t]{2}{*}{ Driver Minor Injury } & .327 & .344 & .344 & .314 & .318 & $=1$ if driver suffered a minor injury, $=0$ otherwise \\
\hline & (.469) & $(.475)$ & $(.475)$ & (.464) & $(.466)$ & \\
\hline \multirow[t]{2}{*}{ Driver Major/Fatal Injury } & .409 & .529 & .425 & .366 & .352 & $=1$ if driver suffered a major injury or died $=0$ \\
\hline & $(.492)$ & (.499) & $(.495)$ & $(.482)$ & $(.478)$ & otherwise \\
\hline \multirow[t]{2}{*}{ Driver Past Accident } & .095 & .092 & .096 & .086 & .099 & $=1$ if driver was in a previous accident in the past \\
\hline & $(.293)$ & $(.289)$ & $(.294)$ & $(.280)$ & (.299) & 3 years, $=0$ otherwise \\
\hline \multirow[t]{2}{*}{ Driver Past Violation } & .329 & .372 & .304 & .308 & .318 & $=1$ if driver was charged with a driving violation \\
\hline & $(.470)$ & $(.483)$ & $(.460)$ & $(.462)$ & $(.466)$ & in the past 3 years, $=0$ otherwise \\
\hline \multicolumn{7}{|l|}{ Crash-level characteristics } \\
\hline \multirow{2}{*}{ Persons in Crash } & 5.89 & 5.98 & 5.47 & 5.73 & 5.98 & Number of persons involved in the crash \\
\hline & $(4.18)$ & $(2.90)$ & $(2.45)$ & $(6.27)$ & $(4.18)$ & \\
\hline \multirow[t]{2}{*}{ One-Car Crash } & .353 & .537 & .268 & .256 & .297 & $=1$ if crash was a one-car crash, $=0$ otherwise \\
\hline & $(.478)$ & (.499) & $(.443)$ & $(.436)$ & $(.457)$ & \\
\hline \multirow[t]{2}{*}{ Two-Car Crash } & .484 & .389 & .536 & .540 & .509 & $=1$ if crash was a two-car crash, $=0$ otherwise \\
\hline & $(.500)$ & (.488) & (.499) & (.499) & $(.500)$ & \\
\hline \multirow{2}{*}{ Three-Plus-Car Crash } & .163 & .074 & .196 & .204 & .194 & $=1$ if crash was a three-plus-car crash, $=0$ \\
\hline & $(.370)$ & $(.261)$ & $(.397)$ & $(.403)$ & $(.395)$ & otherwise \\
\hline \multirow[t]{2}{*}{ Speed Limit $<55 \mathrm{MPH}$} & .379 & .319 & .332 & .379 & .423 & $=1$ if speed limit was less than $55 \mathrm{mph},=0$ \\
\hline & $(.485)$ & $(.466)$ & $(.471)$ & $(.485)$ & $(.494)$ & otherwise \\
\hline Rural Road & .590 & .670 & .623 & .549 & .550 & $=1$ if crash was on a rural road, $=0$ otherwise \\
\hline & $(.492)$ & $(.470)$ & $(.485)$ & $(.498)$ & $(.498)$ & \\
\hline Early Morning & .067 & .108 & .049 & .059 & .051 & $=1$ if crash occurred during the early morning \\
\hline & $(.251)$ & $(.310)$ & $(.216)$ & $(.236)$ & $(.220)$ & hours $(1: 00$ a.m. to 5:59 a.m.), $=0$ otherwise \\
\hline Daytime & .757 & .714 & .830 & .767 & .764 & $=1$ if crash occurred during the daytime hours \\
\hline & $(.429)$ & $(.452)$ & $(.376)$ & $(.423)$ & $(.425)$ & $(6: 00$ a.m. to $7: 59$ p.m. $),=0$ otherwise \\
\hline Evening & .174 & .176 & .121 & .173 & .184 & $=1$ if crash occurred during the evening hours \\
\hline & $(.379)$ & $(.381)$ & $(.326)$ & $(.378)$ & $(.387)$ & (8:00 p.m. to $12: 59$ a.m.),$=0$ otherwise \\
\hline Weekend & .459 & .461 & .414 & .447 & .471 & $=1$ if crash occurred during the weekend (Friday, \\
\hline & (.498) & (.499) & (.493) & (.497) & (.499) & 6:00 p.m. to Monday, 5:59 a.m.), $=0$ otherwise \\
\hline 2008 & .141 & .179 & .050 & .071 & .163 & $=1$ if crash occurred during $2008,=0$ otherwise \\
\hline & $(.348)$ & $(.384)$ & $(.218)$ & $(.257)$ & (.369) & \\
\hline 2009 & .135 & .160 & .046 & .088 & .156 & $=1$ if crash occurred during $2009,=0$ otherwise \\
\hline & $(.342)$ & $(.366)$ & $(.210)$ & $(.284)$ & $(.363)$ & \\
\hline 2010 & .138 & .143 & .117 & .124 & .146 & $=1$ if crash occurred during $2010,=0$ otherwise \\
\hline & $(.345)$ & $(.350)$ & $(.322)$ & (.329) & $(.353)$ & \\
\hline 2011 & .142 & .135 & .156 & .160 & .138 & $=1$ if crash occurred during $2011,=0$ otherwise \\
\hline & $(.350)$ & $(.342)$ & $(.363)$ & $(.367)$ & $(.345)$ & \\
\hline 2012 & .148 & .127 & .197 & .182 & .138 & $=1$ if crash occurred during $2012,=0$ otherwise \\
\hline & $(.355)$ & $(.333)$ & $(.398)$ & $(.386)$ & $(.345)$ & \\
\hline
\end{tabular}




\begin{tabular}{lcccccc} 
& .150 & .137 & .191 & .187 & .136 & $=1$ if crash occurred during $2013,=0$ otherwise \\
& $(.357)$ & $(.344)$ & $(.393)$ & $(.390)$ & $(.343)$ & \\
2013 & .144 & .119 & .242 & .189 & .123 & $=1$ if crash occurred during 2014, =0 otherwise \\
& $(.352)$ & $(.324)$ & $(.429)$ & $(.391)$ & $(.329)$ & \\
$\mathrm{N}$ & 10,845 & 2,946 & 1,057 & 1,780 & 5,062 & \\
\hline
\end{tabular}

Notes: Means (with standard deviations in parentheses) are based on unweighted data from the Fatality Analysis Reporting System (20082014). 
Table 3. Booster Seats and the Probability of Fatality

\begin{tabular}{|c|c|c|c|c|c|c|}
\hline \multicolumn{7}{|c|}{ Panel I: Without sample selection correction } \\
\hline \multirow[b]{2}{*}{ Booster Seat } & \multicolumn{2}{|c|}{ Full sample (Ages 2-8) } & \multicolumn{2}{|c|}{ Ages 2-5 } & \multicolumn{2}{|c|}{ Ages 6-8 } \\
\hline & $\begin{array}{c}-.108 * * * \\
(.016)\end{array}$ & $\begin{array}{c}-.103 * * * \\
(.016)\end{array}$ & $\begin{array}{c}-.102 * * * \\
(.021)\end{array}$ & $\begin{array}{c}-.098 * * * \\
(.022)\end{array}$ & $\begin{array}{c}-.120 * * * \\
(.023)\end{array}$ & $\begin{array}{c}-.109 * * * \\
(.023)\end{array}$ \\
\hline Child Seat & $\begin{array}{c}-.200 * * * \\
(.012)\end{array}$ & $\begin{array}{c}-.186 * * * \\
(.014)\end{array}$ & $\begin{array}{c}-.212 * * * \\
(.014)\end{array}$ & $\begin{array}{c}-.185 * * * \\
(.017)\end{array}$ & $\begin{array}{c}-.199 * * * \\
(.028)\end{array}$ & $\begin{array}{c}-.174 * * * \\
(.028)\end{array}$ \\
\hline Seat Belt Only & $\begin{array}{c}-.205^{* * *} * \\
(.010)\end{array}$ & $\begin{array}{c}-.173 * * * \\
(.012)\end{array}$ & $\begin{array}{c}-.200 * * * \\
(.015)\end{array}$ & $\begin{array}{c}-.170 * * * \\
(.016)\end{array}$ & $\begin{array}{c}-.198 * * * \\
(.014)\end{array}$ & $\begin{array}{c}-.176 * * * \\
(.016)\end{array}$ \\
\hline Probability of death with no restraint & \multicolumn{2}{|c|}{.311} & \multicolumn{2}{|c|}{.324} & \multicolumn{2}{|c|}{.296} \\
\hline Hypothesis tests (p-values) & & & & & & \\
\hline Booster Seat $=$ Child Seat & .000 & .000 & .000 & .000 & .011 & .027 \\
\hline Booster Seat $=$ Seat Belt Only & .000 & .000 & .000 & .000 & .000 & .000 \\
\hline Child Seat $=$ Seat Belt Only & 619 & .243 & .287 & .207 & .958 & .904 \\
\hline $\mathrm{N}$ & 10,845 & 10,845 & 5,467 & 5,467 & 5,378 & 5,378 \\
\hline
\end{tabular}

\section{Panel II: With sample selection correction}

\section{Booster Seat}

Child Seat

Seat Belt Only

Probability of death with no restraint

Hypothesis tests (p-values)

Booster Seat $=$ Child Seat

Booster Seat $=$ Seat Belt Only

Child Seat $=$ Seat Belt Only

$\mathrm{N}$
Full sample (Ages 2-8)

$-.089 * * * \quad-.060 * * *$

(.027) (.022)

$-.087 * * * \quad-.063 * * *$

(.026)

$-.096 * * *$

$(.025)$
(.022)

$-.064 * * *$

(.020)

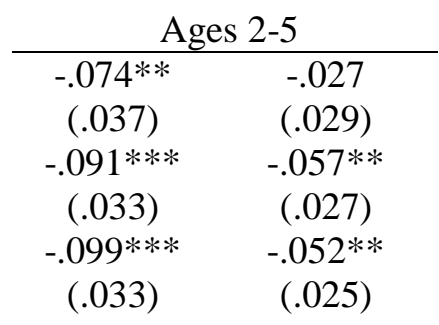

.115

\begin{tabular}{cc}
\multicolumn{3}{c}{ Ages 6-8 } \\
\hline$-.111 * * *$ & $-.099 * * *$ \\
$(.032)$ & $(.031)$ \\
$-.067 *$ & -.045 \\
$(.040)$ & $(.038)$ \\
$-.093 * * *$ & $-.075 * *$ \\
$(.032)$ & $(.030)$
\end{tabular}

.111

Covariates listed in Table 2

$\begin{array}{ll}.818 & .858 \\ .551 & .754 \\ .239 & .919\end{array}$

2,752

2,752

No

Yes
.357

.163

.345

.115

.190

.584

1,298

1,298

Yes

No
.078

.000

.301

1,454

1,454

* Statistically significant at $10 \%$ level; ** at $5 \%$ level; *** at $1 \%$ level.

Notes: Each column within each panel represents the results from a separate OLS regression based on data from the Fatality Analysis Reporting System (2008-2014). The dependent variable is equal to one if the child died in the accident, and is equal to zero otherwise. The restraint-type estimates should be interpreted as relative to no restraint use. The models that control for the covariates listed in Table 2 also control for interactions between driver injuries and driver seat belt status. The models based on the sample selection correction also control for characteristics of the other vehicle (weight and type) and the other driver (seat belt status, accident history, and prior driving violation charges) involved in the crash. Standard errors, corrected for clustering at the vehicle level, are in parentheses. 